\title{
HORVÁTORSZÁG EURÓPAI INTEGRÁCIÓJA A MAKROÖKONÓMIAI MUTATÓK TÜKRÉBEN
}

\author{
Dr. Ph.D. Kotosz Balázs \\ föiskolai docens, Szegedi Tudományegyetem Mérnðki Kar, Szeged
}

\section{SUMMARY}

The collapse of communist economies in Eastern Europe and former Soviet Union, as well as their subsequent transition towards market economies, was arguably one of the most far-reaching economic events of the $20^{\text {th }}$ century. Pain accompanied the economic transition process; all countries experienced a major fall in output after the start of reforms. The growth performance in transition economies was widely different by countries. The paper is looking for the reasons of the growth differences. Even if the initial conditions did not give the same possibilities to governments, early reforms has opened the way to market processes, which seems to be more efficient than state owned institutions in transition economies. In this context, the lower is the state participation, the highest is growth. Empirical analyses justify that GDP growth is higher in countries where state reallocation is decreasing and where tight fiscal policy has been kept.)

\section{BEVEZETÉS}

Az 1980-as években sorra jelentkeztek azok a válságjelek, amelyek elörevetitették a kommunizmus bukását. Kelet-Európa országaiban a gazdasági egyensúlytalanság különböző formái nyilvánultak meg, a politikai reformmozgalmak megerősödtek, egyre erősebb nyomás nehezedett a politikai vezetésre a gazdasági változások megindítására. Az évtized végére több országban a gazdasági növekedést a GDP, a termelés csökkenése váltotta fel, ami nélkülözhetetlenné tette a reformfolyamatok felgyorsulását. A politikai változások az esetek nagyobb részében békésen végbementek, néhány országban fegyveres konfliktusok is kibontakoztak (Litvánia, Románia), Jugoszlávia pedig többéves polgárháborúba sodródott.

\section{AZ ÁTMENET POLTIKAI GAZDASÁGTANÁRÓL}

A politikai váltás viszonylagos békéje ellenére az első pillanattól kezdve világos volt az elemzők számára, hogy a gazdasági rendszerváltás nem mehet végbe fájdalommentesen. A demokratikus intézményrendszerek kiépítése már az átmenet legelső időszakában megindult, azonban a keleti piacok összeomlása következtében szükséges struktúraváltás hosszú éveket igényel(t). Az 1990-es évek elején valamennyi kelet-európai gazdaság jelentös visszaesést élt át, a GDP volumene 15 és $66 \%$ közti mértékben esett vissza a rendszerváltást megelöző idöszakhoz képest. ${ }^{8}$ (Fischer-Sahay, 2000; Rathery, 2003)

A kezdeti tanácstalanság után a szükséges reformlépések halmazáról kialakult egy viszonylag egységes álláspont a vezető közgazdászok körében (ezt szokás washingtoni konszenzus néven emlegetni). Az ütemezéssel kapcsolatban már jelentősebb viták folytak, hiszen a jogi és intézményi feltételek megteremtése csak párhuzamosan mehetett végbe. Az egyes elemekre vonatkozóan egy viszonylag széles körben elfogadott álláspontot mutat az 1 . ábra.

A bizonytalanságot jól jelzi Olivier Blanchard tanulmánya is, amely szerint „a gazdaságpolitika túlságosan nem tehető felelössé az output csökkenéséért, de nem annak érdeme a fellendülés sem." (Blanchard, 1997, 51) Ennek ellentmond azzal a megállapításával, hogy a nyugat-európai tapasztalatokkal szemben „a gazdaságpolitika nem csak az egyensúlyi

\footnotetext{
${ }^{8}$ Bosznia-Hercegovinát leszámitva, ahol a polgárháborúk pusztitásai miatt a visszaesés a becslések szerint meghaladta a 85 \%-ot. (Commission des Communautés Européennes, 2003)
} 
pálya körüli ingadozásokat alakítja, hanem az egyensúlyi pálya meghatározásáért is felelös". (Blanchard, 1997, 51)

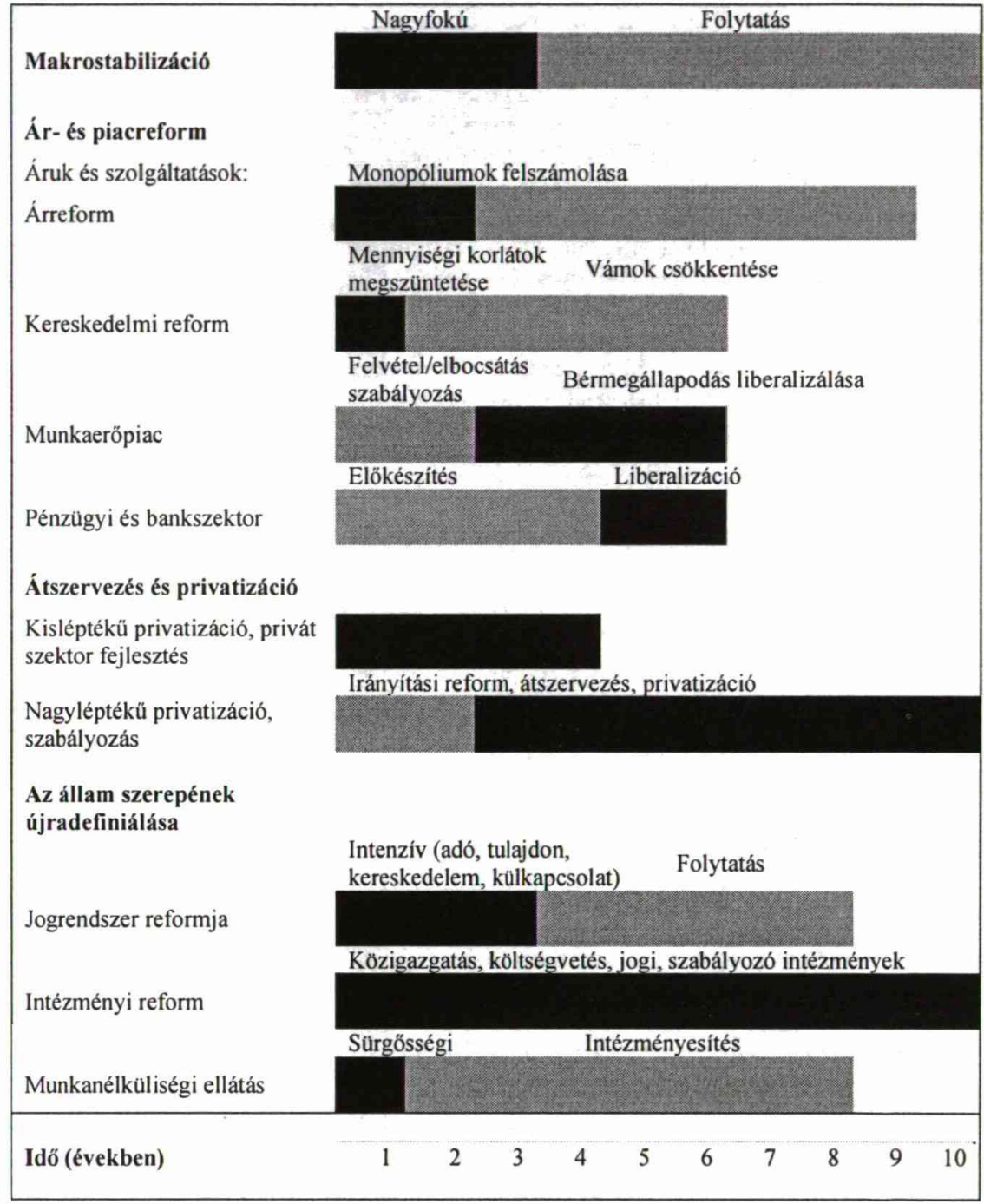

\section{1. ábra. A reformok ütemezése}

Forrás: Fischer - Gelb (1991)

\section{AZ ÁTMENET MUTATóI}

Összefoglalóan elmondhatjuk, hogy minél hosszabb ideig tartott a visszaesési periódus (azaz minél lassabban indultak meg az érdemi reformok), annál nagyobb mértékü hanyatlás következett be (ld. 1. táblázat). Ugyanakkor nagyobb mértékü visszaesést követően az átlagos növekedési ütem is jelentősebb volt (a két változó közti parciális korrelációs együttható minden szinten szignifikáns). 
Ha a makrogazdasági teljesítmény alakulása szerint klaszteranalízis segítségével próbáljuk osztályozni az egyes országokat, különböző csoportszámok esetén érdekes eredményekre juthatunk. Az egyes klaszterek középpontjai minden esetben az előző bekezdésben bemutatott összefüggések mentén alakulnak ki. Minden csoportszám esetén egy csoportba kerül Bosznia-Hercegovina, Moldova, Szerbia-Montenegró és Ukrajna, ezek az országok mutatták fel minden tekintetben a leggyengébb teljesítményt. Sok klaszter esetén Lengyelország kiugróan jó teljesítménye külön „csoportot” eredményez. Ami első látásra kissé meglepő: Albánia minden esetben egy kategóriát képez Csehországgal, Magyarországgal, Szlovákiával és Szlovéniával. Ez Albánia relatíve jó teljesítményének köszönhető, abszolút mértékben mérve Albánia Kelet-Európa legszegényebb országai közé tartozik.

1. táblázat. Visszaesés és növekedés a rendszerváltást követően

\begin{tabular}{|c|c|c|c|}
\hline Ország & $\begin{array}{c}\text { A növekedés } \\
\text { kezdete (év) }\end{array}$ & $\begin{array}{c}\text { Átlagos növekedési } \\
\text { ütem a növekedés } \\
\text { kezdetétöl (\%) }\end{array}$ & $\begin{array}{c}\text { A 2003-as GDP } \\
\text { 1989-es GDP } \\
\text { \%-ában }\end{array}$ \\
\hline Albánia & $1993^{\mathrm{b}}$ & 6,5 & 120,1 \\
\hline Bosznia-Hercegovina & 1995 & 15,5 & 62,1 \\
\hline Bulgária & 1998 & 4,3 & 69,4 \\
\hline Csehország & 1993 & 1,9 & 105,8 \\
\hline Észtország & $1995^{\mathrm{b}}$ & 5,0 & 98,3 \\
\hline Fehéroroszország & 1996 & 5,6 & 97,7 \\
\hline Horvátország & 1994 & 4,3 & 95,3 \\
\hline Lengyelország & 1992 & 4,1 & 139,6 \\
\hline Lettország & 1994 & 4,7 & 74,7 \\
\hline Litvánia & $1995^{\mathrm{b}}$ & 4,8 & 90,3 \\
\hline Macedónia & 1996 & 1,8 & 115,0 \\
\hline Magyarország & 1994 & 3,5 & 40,1 \\
\hline Moldova & 2000 & 5,3 & 92,9 \\
\hline Románia & $1993^{\mathrm{c}}$ & 2,0 & 51,9 \\
\hline Szerbia és Montenegró & $2000^{\mathrm{a}}$ & 4,6 & 113,8 \\
\hline Szlovákia & 1994 & 4,2 & 120,6 \\
\hline Szlovénia & 1993 & 3,8 & 45,2 \\
\hline Ukrajna & 2000 & 6,3 & \\
\hline Forrás: IMF & 2004 & $2001)$ & \\
\hline
\end{tabular}

Forrás: IMF (2004), European Commission (2001) alapján saját számitás

Az árak liberalizációjának szükségszerủ velejárójaként az infláció felgyorsult. Az átmenet országai közül az infláció féken tartásában Magyarország mutatta fel a legjobb teljesítményt, hiszen a legmagasabb éves infláció is csak 35 \%-os volt, míg Jugoszláviában 1993 októbere és 1994 januárja között 1,3·10 22 -ed részére értékelték le a dínárt, ami a gazdaságtörténet egyik legnagyobb hiperinflációját jelzi. (Federal Statistical Office, 2003) Az infláció alakulását nagyban befolyásolta, hogy az adott ország milyen árfolyamrendszert választott. Nagyobb eséllyel biztosította az árak kézbentartását a fix árfolyam, mint a rugalmas, a választás azért esett mégis több országban a rugalmas árfolyamrendszerre, mert megfelelő devizatartalékok hiányában így tudtak jobban védekezni a reál sokkok ellen.

A hiperinfláció időszakában az országban jelenlévő stabil valuta (a volt Szovjetunió területén elsősorban az amerikai dollár, Jugoszláviában inkább a német márka) vette át a pénz klasszikus szerepeit, majd a stabilizáció során általában ezekhez a kulcsvalutákhoz kötötték az új pénz árfolyamát. Az árak viszonylagos stabilitását az évtized végére a legtöbb országban sikerült elérni, az infláció egyjegyủre (esetleg kétjegyüre) zsugorodott. A stabilizációt követően azonban mindenképpen szükségessé vált rugalmasabb rendszer felé mozdulni, ugyanis a nagymértékü tökemozgás és a tarthatatlan költségvetési politika az orosz válsághoz hasonló jelenségekhez vezethet. (Fischer-Sahay, 2000) 


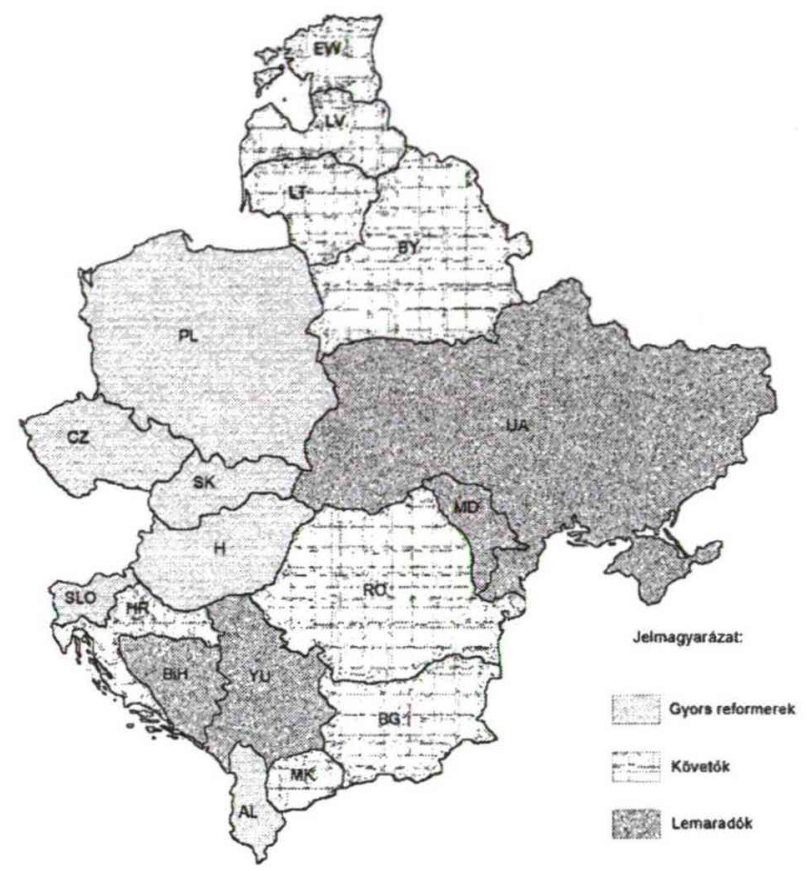

2. ábra. Országcsoportok a makrogazdasági teljesítmény növekedése alapján Forrás: A szerző saját szerkesztése

2. táblázat. Gyorsuló és megfékezett infláció a rendszerváltás után

\begin{tabular}{|l|r|r|r|}
\hline \multicolumn{1}{|c|}{ Ország } & $\begin{array}{c}\text { A legmagasabb } \\
\text { infláció mértéke (\%) }\end{array}$ & $\begin{array}{c}\text { A legmagasabb } \\
\text { infláció éve }\end{array}$ & $\begin{array}{c}\text { Átlagos infláció } \\
(\%)\end{array}$ \\
\hline Albánia & 226,0 & 1992 & 24,7 \\
\hline Bosznia-Hercegovina & 5,8 & 1997 & 1,0 \\
\hline Bulgária & 1082,0 & 1997 & 13,7 \\
\hline Csehország & 52,0 & 1991 & 49,4 \\
\hline Észtország & 1076,0 & 1992 & 208,7 \\
\hline Fehéroroszország & 1190,2 & 1993 & 84,8 \\
\hline Horvátország & 1517,5 & 1993 & 36,1 \\
\hline Lengyelország & 585,8 & 1990 & 44,3 \\
\hline Lettország & 951,2 & 1992 & 59,7 \\
\hline Litvánia & 1020,5 & 1992 & 80,0 \\
\hline Macedónia & 1664,4 & 1992 & 17,6 \\
\hline Magyarország & 35,0 & 1991 & 92,7 \\
\hline Moldova & 1276,4 & 1992 & 73,5 \\
\hline Románia & 256,1 & 1993 & 1465,9 \\
\hline Szerbia és Montenegró & $1,165^{* 10} 10^{14}$ & 1993 & 12,8 \\
\hline Szlovákia & 61,2 & 1991 & 42,7 \\
\hline Szlovénia & 549,7 & 1990 & 143,4 \\
\hline Ukrajna & 4734,0 & 1993 & 65,9 \\
\hline Összesen & 1017,4 & 1992 & \\
\hline
\end{tabular}

Forrás: EBRD, 1996-2004 alapján saját számítás 


\section{HORVÁTORSZÁG}

Az önálló Horvát Köztársaság kikiáltása után nagy erőkkel indult meg az önálló gazdaság müködési feltételeinek megteremtése. Az időközben kitört háború, a hadigazdálkodásból adódó költségvetési kiadások pénzkibocsátással történő fedezése az infláció felpörgéséhez vezetett. A gazdasági liberalizáció jelentős állomása a 2000-ben megválasztott új, Európa-barát kormány, amely már az uniós csatlakozás jegyében igyekszik alakítani gazdaságpolitikáját.

A horvát költségvetés az 1993-94-es stabilizációt követően strukturálisan meglehetősen stabil. Kiemelkedően magas volt az állami újraelosztás aránya, az 1990-es években ez a mutató az 50 \%-ot is meghaladta, de az ezredfordulóra már csökkenő tendenciát mutatott. A bevételek között nagyobb arányt képviselnek a közvetett adók (18-20\%), a forgalmi és hozzáadottérték-adó a GDP $15 \%$-a körüli értéket mutat, kétszerese a keleteurópai átlagnak, de a fogyasztási adókról is hasonló állítható. A kiadási oldalon lassú átrendeződés figyelhető meg, az áruk és szolgáltatások vásárlása lassan csökken (15\%-ról 10 \% körüli szintre), míg a háztartások támogatása hasonlóan nő (12-ről 17 \%-ra). Az erősen központosított államapparátus fenntartása az átlagosnál nagyobb mértékủ forrásokat igényel. A 2000-es évet leszámítva a fiskális egyenleg elfogadható mértékü hiányt mutat, az elsődleges egyenleg általában pozitív. Jelentősebb törés 1999-2000-ben mutatkozott a költségvetés számaiban, Horvátország esetén ez nem elsősorban az orosz válsággal, hanem a Jugoszlávia elleni embargóval és légicsapásokkal magyarázható.

Az ezredforduló után Horvátország makrogazdasági teljesítményét már nem az átmenetet jellemző washingtoni, hanem az európai integrációt meghatározó brüsszeli konszenzushoz mérhetjük. Ahogy a 3. ábra is mutatja, Horvátország Szlovénia után a második legfejlettebb jugoszláv utódállam, fejlettsége meghaladja a közép- és kelet-európai átlagot, sőt a 4. ábra szerint az 1986 óta uniós tag Portugália szintjét is.

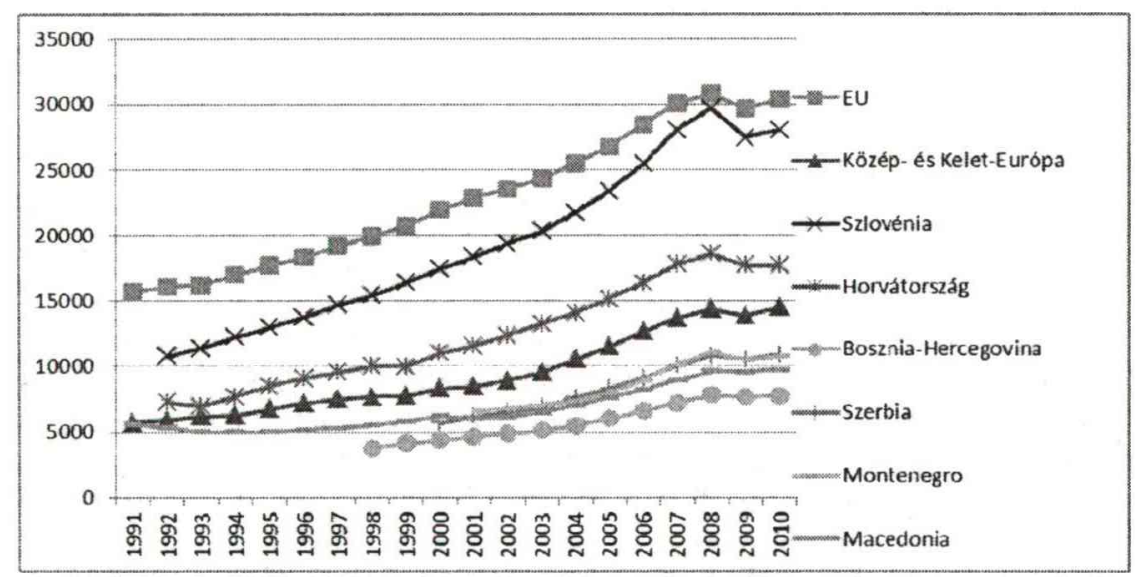

\section{3. ábra. Jugoszláv utódállamok egy főre jutó GDP-je PPP-ben}

Forrás: IMF (2011) alapján saját szerkesztés

$\mathrm{Az}$ állam jövedelem újraelosztó szerepe a XXI. század eleji piacgazdaságokban ideálisnak tartott 40-45\%-os szinten mozog Horvátországban (5. ábra), alig haladja meg a fejlett gazdaságok átlagát, és jóval alatta marad az Európai Unió mutatójának. Az inflációs ráta az ezredforduló óta jellemzően az EU átlagának közvetlen közelében mozog, egyedül 2008-ban haladta azt meg 2 százalékponttal, ráadásul a többi balkáni országgal ellentétben viszonylag stabil. 


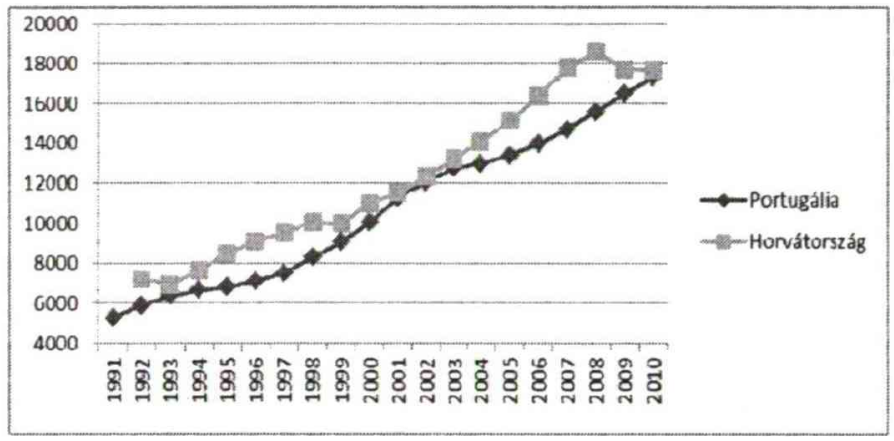

4. ábra. Horvátország és Portugália egy före jutó GDP-je PPP-ben

Forrás: IMF (2011) alapján saját szerkesztés

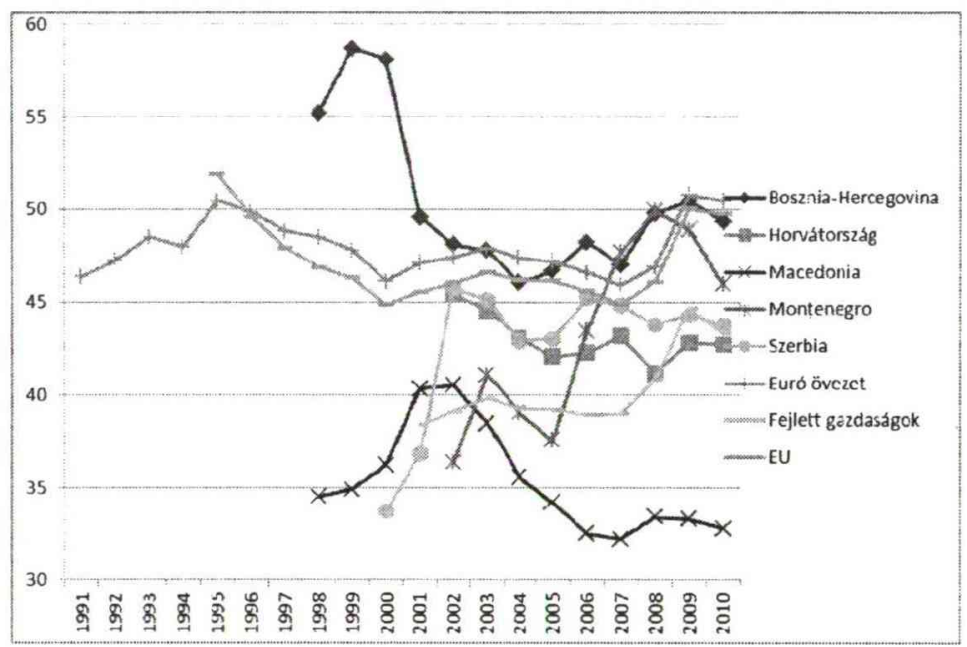

5. ábra. Az állami újraelosztás aránya (\%)

Forrás: IMF (2011) alapján saját szerkesztés

A horvát állam gazdálkodása megfelel az európai elvárásoknak, 2004 óta eleget tesz a maastrichti konvergencia kritériumokban megfogalmazott - államháztartásra vonatkozó sarokszámoknak. Az államháztartás GDP arányos hiánya 3\% alatt maradt, 2008-tól pedig az euró övezet átlagánál is kedvezőbb. A bruttó államadósság jelenleg sem éri el a GDP $50 \%$-át, az elörejelzések 5 éves távlatban is csak mérsékelt növekedést és $60 \%$ alatti arányszámot mutatnak (6. ábra). 


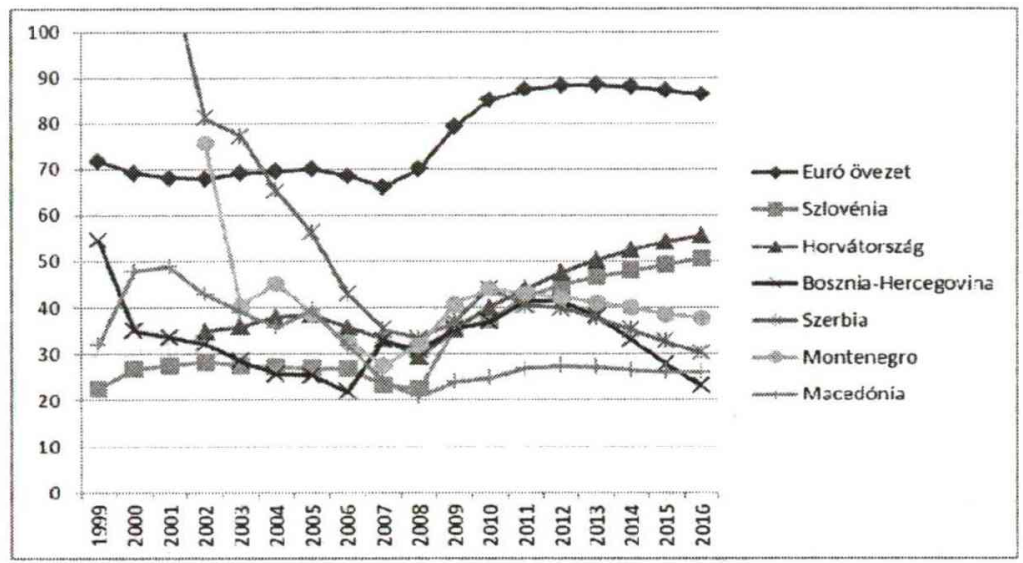

6. ábra. Az államháztartás bruttó adóssága a GDP százalékban Forrás: IMF (2011) alapján saját szerkesztés

\section{5. ÖSSZEFOGLALÁS}

Horvátország a rendszerváltó országok középmezőnyében foglalt helyet - mind makrogazdasági teljesítménye, mind a reformok sebességét illetően. 2007 óta már nem csak a kedvezőbb pályát befutó, de a vele azonos kategóriába tartozó országok is az Európai Unió tagjai, ugyanakkor Horvátország csatlakozásának még várható időpontja sem látható. $\mathrm{Az}$ adósságválság és az euróövezet széthullásának árnyékában talán kevéssé vigasztaló tény, hogy az euró bevezetésének formális követelményeit teljesíti. Az is bizonyításra került, hogy az ország nem makrogazdasági teljesítménye miatt nem válhatott még az Európai Unió tagjává, annak elsősorban jogi és politikai okai vannak.

\section{IRODALOMJEGYZÉK}

Commission des Communautés Européennes (2003): Le processus de stabilisation et d'association en faveur de l'Europe du Sud-Est. Deuxième Rapport. COM, Bruxelles. 37 p. EBRD Transition Report évkönyvek különböző számai 1994-2003. European Bank of Reconstruction and Development, London.

European Commission (2001): Bosnia and Herzegovina. Country Strategy Paper 20022006. EC, Brussels. 71 p.

Federal Statistical Office (2003): Statistical Pocket Book. Federal Statistical Office, Beograd.

Fischer, S. - Gelb, A. (1991): Issues in Socialist Economy Reform. Journal of Economic Perspective, Vol. 5, No. 4. pp. 91-105.

Fischer, S. - Sahay, R. (2000): The Transition Economies After Ten Years. NBER Working Paper $\mathrm{n}^{\circ} 7664$, National Bureau of Economic Research.

IMF (2004): World Economic Outlook Database. International Monetary Fund, Washington, D.C.

IMF (2011): World Economic Outlook Database. International Monetary Fund, Washington, D.C.

Rathery, A. (2003): Evolution macro-économique des pays en transition et consequences sur les transports. Conférence IRU Est-Ouest, 15-16 mai 2003, Budapest. 